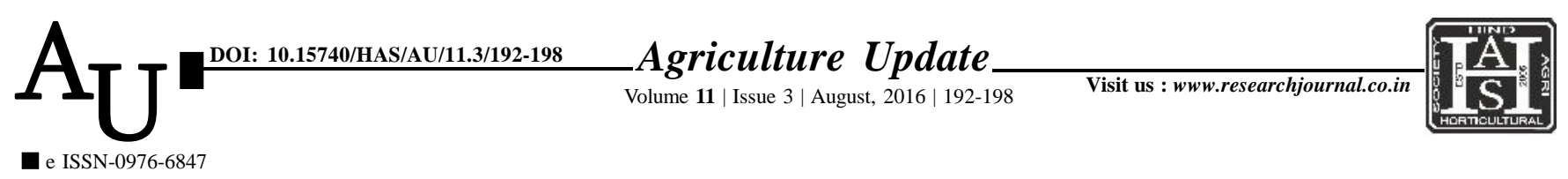

\title{
Research Article: Social economics traits of pea growers in Kota region of Rajasthan
}

\section{N.R. MEENA, F.L. SHARMA AND NARPAT SINGH}

Article Chronicle: Received : 14.04.2016;

Revised :

05.06.2016;

Accepted :

18.06.2016

KEY WoRDS:

Social economics, Pea growers, Tribe

Author for correspondence :

\section{N.R. MEENA}

Department of Extension Education, Rajasthan

College of Agriculture, Maharana Pratap

University of Agriculture and Technology, UDAIPUR (RAJASTHAN) INDIA

Email: nrmeena1985@ gmail.com

See end of the article for authors' affiliations
SUMMARY : The present study were aimed to study the social economic traits of pea growers in Kota region of Rajasthan. Kota region consists of five districts, out of which three districts namely Bundi, Kota and Tonk were selected purposively on the basis of maximum area under pea cultivation. Two tehsils from each identified districts were selected on the basis of maximum area under pea cultivation. Thus, in all six tehsils were taken for the present study. It was found that out of the total respondents, 44.00 per cent respondents were from middle age group of 34 to 56 years, whereas 23.00 per cent farmers were from old age group (above 56 years) and only 33.00 per cent were found in the young age group i.e. below 34 years. Findings indicated that 30.50 per cent farmers were in the illiterate group while, 43.50 per cent farmers were in the literate group (upto secondary level) and only 26.00 per cent of total respondents were educated above secondary level in the study area. It is evident from the study that out of 200 respondents, 39.00 per cent farmers were from general caste, while 22.50 per cent farmers were from other backward caste (OBC) category and 18.00 per cent farmers were from schedule caste (SC), only 20.50 per cent respondents were from the schedule tribe group. Further, it was found that 19.00, 20.00, 23.00 and 38.00 per cent small farmers were from SC, ST, OBC and higher caste group respectively. Whereas, 17.00, 21.00, 22.00 and 40.00 per cent marginal farmers were found from SC, ST, OBC and higher caste group respectively. The study reported that majority (65.00\%) of total respondents belonged to agriculture as a main occupation whereas, 22.50 per cent and 12.50 per cent respondents were found to be from service / business + agriculture and agriculture with caste occupation group, respectively. It was also reported that among marginal respondents, 68.00, 12.00, and 20.00 per cent had agriculture, agriculture with caste occupation and agriculture + service / business occupation respectively. While, 62.00, 13.00 and 25.00 per cent small farmers possessed agriculture, agriculture with caste and agriculture + service/ business occupation, respectively.

How to cite this article : Meena, N.R., Sharma, F.L. and Singh, Narpat (2016). Social economics traits of pea growers in Kota region of Rajasthan. Agric. Update, 11(3): 192-198, DOI : 10.15740/HAS/AU/11.3/192-198. 